\title{
頸䯣症に対する前方除圧固定術の治療経験
}

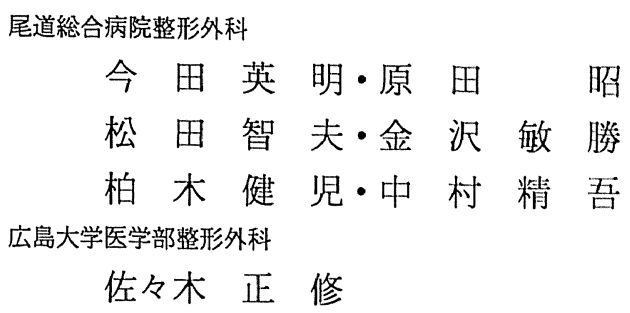

\section{A Clinical Study of Anterior Interbody Fusion for Cervical Myelopathy by}

\author{
Hideaki Imada, Akira Harada, Toshio Matuda, Toshikatu Kanazawa, \\ Kennji Kashiwagi and Seigo Nakamura \\ Department of Orthopaedic Surgery, Onomichi General Hospital \\ Masanobu Sasaki
}

Department of Orthopaedic Surgery, Hiroshima University of Medicine, Hiroshima Japan

\begin{abstract}
We performed anterior interbody fusion in 17 patients with cervical myelopathy because of cord compression at one intervertebral level. In all cases, radiographic examination showed cervical disc herniation, and 9 patients had associated spondylotic changes, and 3 patients had ossification of the posterior longitudinal ligament (OPLL)

Since favorable response was not achieved in 2 patients after the initial operation, we additionally performed expansive laminoplasty. Both of these cases were accompanied by cervical canal stenosis.

In this report, the authors describe their postoperative results and reconsider the indications for anterior interbody fusion.
\end{abstract}

Key words : Cervical myelopathy (頸骼症), Anterior interbody fusion (前方固定術), Cervical canal stenosis（頸部脊椎管狭窄症）

はじめに

压迫往脊䯣症のなかで, 責任高位が一椎間と思われ た应可に対して，我々は，前方除圧固定術を第一選択 こしてきたが，少数ではあるが，成績不良例を経験し ている. 今回我々は, 手術成績をX線学的検査を含め て諳育し, 成績不良例の病態, および術式の妥当性に つ:て族討を行ったので報告する.
対

象

1988 年以来, 当科において, 一椎間の前方除圧固 定術を行った症例は，17 例（男性 13 例，女性 4 例） で，年齢は 40 歳 75 歳（平均 54.5 歳）である. 発症 から手術までの期間は，1ヶ月〜37ヶ月（平均 10.3 ヶ月）であり，術後経過観察期間は， $3 \sim 84$ ヶ月 （平均 32.2 ヶ月）であった．固定椎間は， C5/6:11 例, $\mathrm{C} 4 / 5: 3$ 例, $\mathrm{C} 6 / 7: 2$ 例, $\mathrm{C} 3 / 4: 1$ 例であった. 


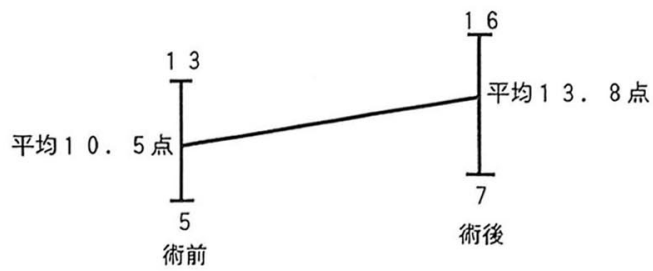

図 1 JOA score の变化

\begin{tabular}{|c|c|c|}
\hline 假 & (75\%以上) & 9 例 \\
\hline 良 & （50\%以上 $75 \%$ 末満） & 5 例 \\
\hline 可 & (25\%以上 $50 \%$ 未満) & 1 例 \\
\hline 不可 & ( $0 \%$ 以 $25 \%$ 未満) & 2 例 \\
\hline
\end{tabular}

\begin{tabular}{|c|c|}
\hline 頸椎椎間板ヘルニア & 6 例 \\
\hline 頸椎椎間板ヘルニア+OA & 9 例 \\
\hline 頸椎椎間板ヘルニア+OPLL & 3 例 \\
\hline
\end{tabular}

結

果

全症例とむ一椎間に限局する頸椎椎間板へルニアを 認め, 術中に確認した。手術は, Smith-Robinson 法に準じて施行し, 雨侧ルシュ力闺節外侧まで十分展 開した後, 後級鞆带を露出し, ヘルニア媿を摘出した.

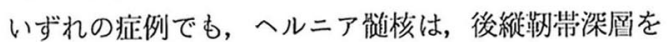

破り，深，浅層間に脱出していた，春䯣症の病型は, 服部分類 II 型：4 例， II 型：13 例であった。 JOA score は, 図 1 の如く, 術前 $5 \sim 13$ 点, 平均 10.5 点 上り術後 $7 \sim 16$ 点, 平均 13.8 点に改善した. 術後成 績は平林法にて算定し，改善率 $75 \%$ 以上を優，50\% 以上 $75 \%$ 未満を良， $25 \%$ 以上 $50 \%$ 未満を可，0\%以 上 $25 \%$ 未満を不可としたところ, 優 9 例, 良 5 例, 可 1 例, 不可 2 例であった（表 1 ). 不可の 2 症例に 対して，後方除圧術を追加した，これにより1例では JOA score は 9 点から 14 点に, あう 1 例では 10 点 加 12 点に改善された。

春椎管前後径を責任高位で計測してみたところ，11 $\mathrm{mm}: 4$ 例, $12 \mathrm{~mm} 2$ 例, $13 \mathrm{~mm}$ : 3 例, $14 \mathrm{~mm}$ : 5 例, $15 \mathrm{~mm}$ : 3 例であり $13 \mathrm{~mm}$ 以下の発育性脊椎 管狭窑の合侀を 9 例（53\%）にみとめた。 また術前単 純レ線にて, 椎体後方の骨棘の合併を 9 例に, 後縦勒 带骨化症（以下 OPLL）の合併を 3 例に認めた（表 2 ). 術後, 単純レ線にて 8 例に隣接椎間の変化を認 めたが，脊髄症が再発した症例は認められなかった。

\section{症 例 1}

68 嵅，女性. 誘因なく両示指汃ら小指にかけての しびれ感にて発症した，服部分類而型の脊䚫症である. 単純レ線にて脊娟道管前後径 $13 \mathrm{~mm}$ で, C5, 6 椎体 後方に分節型 OPLL をみとめ, 占拠率は $12.3 \%$ を゙っ

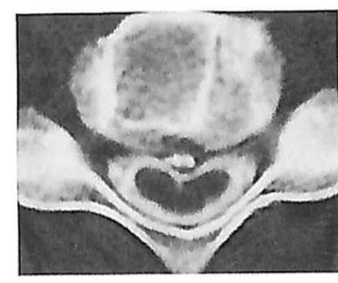

a

図 2 症例 1 術前画像所見

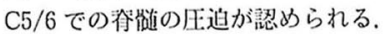

a. $\operatorname{CTM}(\mathrm{C} 5 / 6)$

b. MRI ; T1 强調像

c. MRI; T2 強謂像

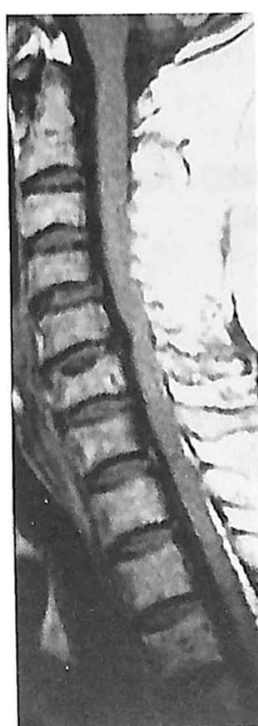

b

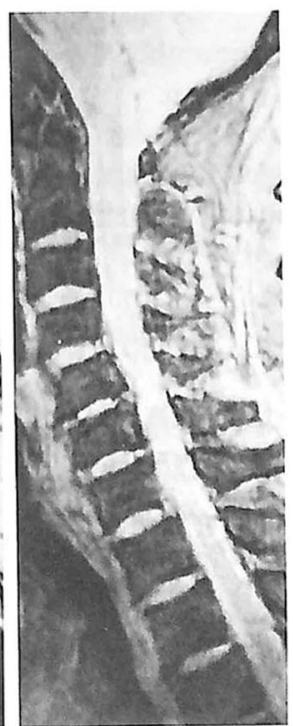

C 


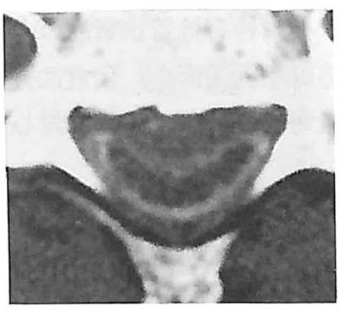

a

図 3 症例 2 術前画像所見 C4/5 での脊爴の圧迫が認められる.
a. $\operatorname{CTM}(\mathrm{C} 4 / 5)$
b. MRI ; T1 強調像
c. MRI ; T2 強調像

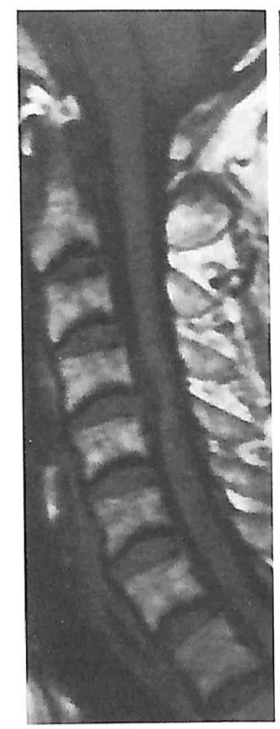

b

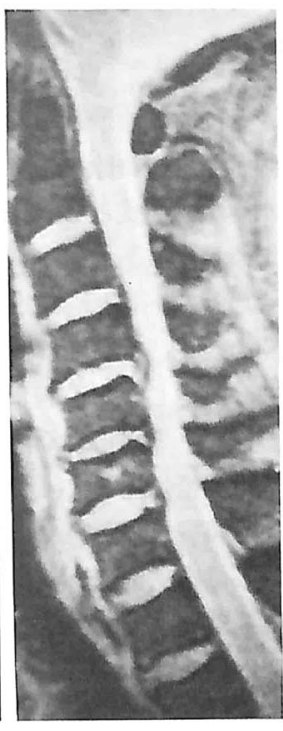

C

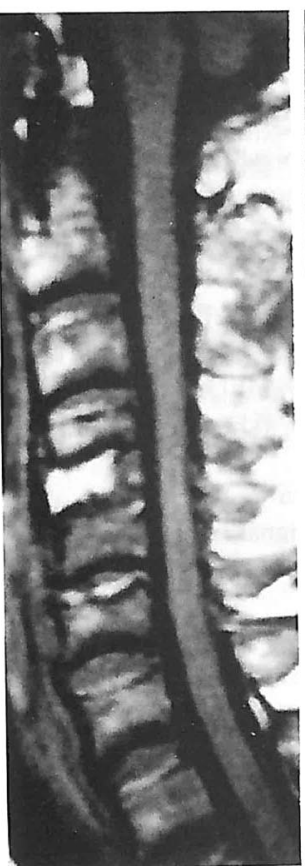

a

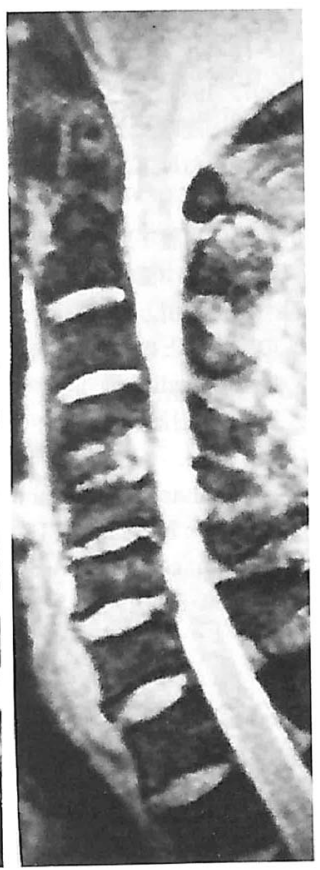

b
図 4 症例 2 前方除圧固定術後 MRI

a. T1 強調像

b. T2 強彫像

術前に比へ资䯣内の高信号領域の拡大を認 めた。
た. 神経学的所見として, 上院三頭筋肬反射の低下と 下肢腱反射の六進，上腕三頭筋筋力の低下を恋め，面 像所見（図 2）と照らし合わせ, 責任高位は C5/6 と 診断し，一椎間の前方除圧固定術を施行した，術後， 右手のしびれ感残存するむ, JOA score は術前 13 点 加術後 16 点に改善し, 平林の改善率は $75 \%$ と経過 良好である。

\section{症 例 2}

68 歳，男性. 誘因なく左中指から小指のしびれ感 にて発症した，服部分類正型の金成正症である，単純レ 線にて脊椎管の狭窄 (前後径 $12 \mathrm{~mm}$ ), および C3〜C5 の椎体後方に占拠率 $21.5 \%$ の分節型 OPLL の合併を 認めた。神経学的所見として, 上焥三頭筋腱反射の低 下，上䛷二頭筋以下の筋力低下を認め，画像众查にて C4/5 に限局した奉髄の圧迫を認めた（図 3 ）. 責任高 位は C4/5 上判断し, 前方除圧固定術を施行した。術 後, JOA score は 9 点之改善を認めず, 術後の MRI では，C 4/5 椎間では除圧は良好で，クモ膜下腔は拡 大していたが，C5/6 椎間で脊髄の圧迫を認め，また MRIT2 強調像にて脊䯣内の高信号域の拡大を認め た2)5778) (図 4). 前方除圧固定術後 9 ヶ月にて奉椎 管狭窄症に対して, C3 からの C7 の椎弓形成術を追 加し, 術後 13 ヶ月の現在, JOA score は, 14 点に改 善している. 


\section{考察}

前方除圧固定術は，動的因子を取り除くことができ， さらに脊噃前方圧迫因子を確実に除去する事が可能で あり，頸椎椎間板ヘルニアの術式として合目的である. しかし，前方除圧固定術は，以下に示すいくつかの問 題点を有している．すなわち，1）固定椎間が多椎間 に及ぶほど，隣接椎間の变化（椎間腔の狭小化，骨棘 形成，椎間板へルニア）が生じやすく，2）除圧固定 箅囲に技術的に制限があり，3）自家骨移植が必要で あり，さらに，4）後方手術に比べて後療法が長期間 を要し，特に高龄者には負担が大きい点である．した がって，我々は，責任高位を一椎間に限局することが 可能である症例にのみ，前方除圧固定術を選択してき $た^{1 / 3)}$. しかし, 症例 2 の如く, 発育性脊椎管狭窄症 を合侀した例では神経学的所見，画像所見のみで責任 高位を決定することが困難と思われ，単一椎間固定術 を選択する上で問題を残していると思われた。

自験例の術前レ線を検討してみたところ，脊椎管前 後径が $13 \mathrm{~mm}$ 以下の発肖性春椎管㹨窄症を合併して いる症例が 9 例 (5.3\%) に認められ，その内 6 例は， 椎体後方骨棘，後緥勒带骨化症等の资椎管狄窄因子を 有していた。 また，術後レ線にて，3例の発育性脊椎 管狄窄症合作例に骨棘の增大，あるいは椎間の狭小化 等の隣接椎間の変化を認めた．国分は脊檤症例の 42 \%に発育性凑惟管狭窄症の合例を認めると報告してお り"，小田らは凅椎管前後径が $12 \mathrm{~mm}$ 以下の症例で は，前方固定術後 3 年以上経過した症例のうち， $40 \%$ に症状の再恶化を慧められると報告している ${ }^{6)}$ 。自験 例屯㝓檤症の再発に対し, 慎重な経過钼察が必要と考 えている，以上の点を踏まえ，見在では，責任高位が

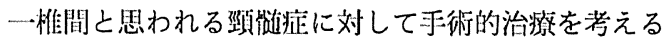

場合, 発育性脊椎管狭窄症の合併のない症例に対して は前方除圧固定術を，発育性脊椎管狭窄症を合併し， かつ後弯変形のない症例に対しては後方除圧術を選択 している.

$$
\text { ま と め }
$$

1. 責任高位が一椎間と思われた頸䯣症に対して前 方除圧固定術を施行した 17 例の手術成績を報告した。

2. 脊椎管狭窄症を合併する症例では，多椎間レべ ルでの圧迫の存在, 隣接椎間への影響を考慮に入れ， 後方除圧術を選択していく方針である.

\section{参 考 文 献}

1）平林 洌: 単一椎間固定例加らみた頸部脊椎症の神経 症状ーとくに顽榷症の高位䛦断について一，臨整外，19： 409-415, 1984.

2）板橋 孝: 頸部脊䟠症に対する術前・術後 MRI の検 討. 日整会誌, $62 ： S 964,1988$.

3）国分正一：頙椎症性脊跶症における責任椎間板高位の 神経学的診断. 臨整外, $19: 417-424,1984$.

4) 国分正一: 頸部椎間板へルニア, 臨整外, $24: 289$ 297, 1989 .

5）西山茂啨, 上田百合人, 松山说啓, 他：頸檤症の手術 前後における MRI の検討。整形外科, $42: 1191-1195$, 1991.

6）小田裕版：頸椎症性脊噵症の手術的治療における術式 の検討，中部日本整災誌，33：1018-1020， 1990.

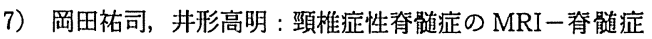
の重症度との関係および術後の予後の推定が可能か一。 Orthopaedics 增刊整形外科 MRI 診断マニュアル，206210, 室田景久, 矢部 裕, 酒句 崇編, 東京, 金原出 版, 1994

8) Takahashi M, Sakamoto $Y$, Miyawaki M, and Bussaka H. : Increased MR signal intensity secondary to chronic cervical cord compression. Neuroradiology $29:$ 550-556, 1987. 